\title{
Fisher hypothesis: UK evidence over
}

\section{a century}

\author{
BRIGITTE GRANVILLE* $\ddagger$ and SUSHANTA MALLICK§ \\ $\ddagger$ Centre for Business Management, Queen Mary, University of London, Mile End \\ Road, London E1 4NS, UK and §Department of Economics, Loughborough \\ University, Ashby Road, Loughborough, Leicestershire LE11 3TU, UK
}

Using annual data over a long time horizon from 1900 to 2000 for the UK, this study finds the existence of a Fisher relation via Johansen cointegration tests. The cointegrating relationship between the two variables suggests a significant long-run equilibrium with a positive coefficient of more than one during the stated period.

\section{INTRODUCTION}

The Fisher relation (Fisher, 1930) states that the nominal interest rate is expressed as the sum of expected constant real interest rates plus expected inflation. This link may not be perfect, as real interest rates can vary following policy changes. If the relation holds, the movements in shortterm interest rates will reflect fluctuations in expected inflation and will therefore be a good indicator of future inflation (Mishkin, 1992). The hypothesis has been subject to intensive tests, ${ }^{1}$ being sensitive both to the time period and technique used, and thereby raising questions as to its validity.

The search for a possible relationship between inflation and interest rates is expected to reflect the policy being followed by the Bank of England (BE) over the period 1900-2000. During certain periods including war, the $\mathrm{BE}$ had to provide liquidity to the government, ignoring financial markets. During other periods its action focused on the financial markets through tightening or easing monetary policy. In many of these cases a disconnection between inflation and interest rates can be expected. In the late 19th century, before monetary systems converged with the gold standard, bond markets were less preoccupied with inflation. ${ }^{2}$ This justifies a starting point of the early 20 th century. For the UK during the period 1900-2000, it is found that the correlation of the three-month T-bill rate with inflation is 0.413 , which is low but positive. Estimating a cointegrating relation, interest rates display a strong equilibrium relation with contemporaneous inflation with a coefficient of 1.36. Theoretical considerations are presented in Section II followed by tests for integration and cointegration in Section III, with concluding remarks in Section IV.

\section{THEORETICAL BACKDROP}

With nominal interest rate $\left(i_{t}\right)$ and inflation $\left(\pi_{t}\right)$, the ex-post real interest rate $\left(r_{t}\right)$ can be written as:

$$
1+r_{t}=\frac{1+i_{t}}{1+\pi_{t}}
$$

Solving for $r_{t}$ :

$$
r_{t}=\frac{i_{t}-\pi_{t}}{1+\pi_{t}}
$$

Ignoring the denominator and assuming constant real interest rates, an ex-ante definition that inflation expectations, $\pi_{t}^{e}$, determine nominal interest rates is:

$$
i_{t}=r+\pi_{t}^{e}
$$

This relation is not estimable. Assuming efficient markets (Fama, 1975), the observed inflation can be decomposed

\footnotetext{
* Corresponding author. E-mail: bgranvil@dircon.co.uk

${ }^{1}$ See for instance Barsky (1987), Crowder and Hoffman (1996), Evans and Lewis (1995), Mishkin (1992), and Granville and Rockinger (1997). For a survey on the relationship between real interest rates and real macroeconomic activity, see Taylor (1999).

${ }^{2}$ See Ferguson (2001): The Money Printers, pp. 142-168.
} 
into its expected component and a forecast error, $u_{t}$, orthogonal to all information at $t$ :

$$
\pi_{t}=\pi_{t}^{e}+u_{t}
$$

Rewriting this in a regression framework:

$$
i_{t}=c_{0}+c_{1} \pi_{t}+e_{t}
$$

Coefficient $c_{0}$ should capture the average real interest rate and $c_{1}$ should be equal to one, which is referred by Mishkin as the full Fisher Effect.

\section{EMPIRICAL RESULTS}

\section{Time-series properties and testing for unit-roots}

Annual data for the UK between 1900 and 2000 are used. The short-term interest rate is the three-month Treasury bill rate $(T B R 3 M U K)$ compiled from the BE publications and inflation (CPINFUK) is from several issues of the Journal of Royal Statistical Society. Figure 1 plots the two time series over the stated period.

Table 1 presents sample statistics for the entire sample and three sub-periods. For the entire period the ex-post real interest rate is positive. Since the period 1936-1970 is characterized as moderately inflationary following the aftermath of great depression and a world war, the average real interest rate turned negative. Subsequently, despite

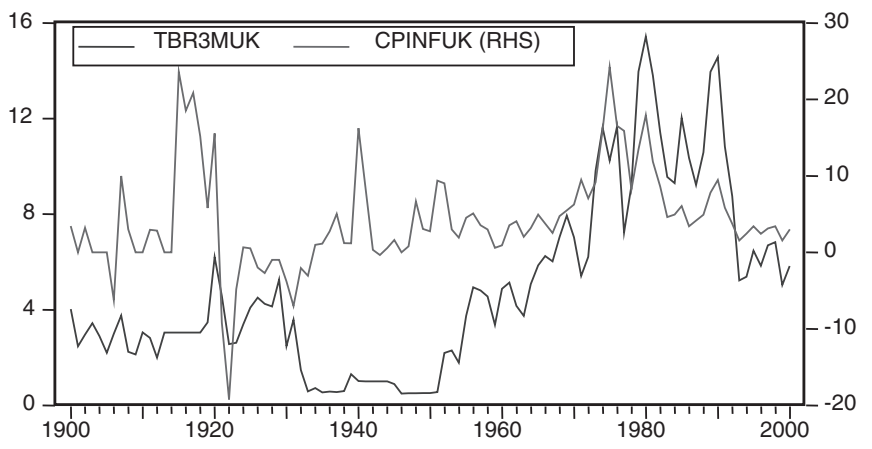

Fig. 1. Interest rate versus inflation rate (\%) inflationary events - two oil price shocks (in 1973 and 1979) - and the recession in 1990, the average real interest rate for the period 1971-2000 was positive, partly due to low inflation in the 1990s via inflation targeting policy.

The integration properties of inflation and interest rates are first tested using Dolado et al. (1990). The most general method for a series $y_{t}$ corresponding to Augmented Dickey-Fuller (ADF) regression with a constant and a trend is

$$
\Delta y_{t}=\alpha_{0}+\alpha_{1} t+\alpha_{2} y_{t-1}+\sum_{j=1}^{K} \beta_{j} \Delta y_{t-j}+u_{t}
$$

The test results are reported in Table 2 .

As in Barsky (1987), inflation is a stationary or white noise process, since the $t$-statistic of -4.46 is much smaller than the critical value of -4.05 at a $1 \%$ significance level, implying price level as I(1). Interest rate follows a random walk, as the $t$-statistic, being greater than the critical value of -4.05 , could not reject the null. Traditional $t$-tests for the drift and trend term showed that neither could be included. For the sub-periods, inflation is I(1) in the first and third, and $\mathrm{I}(0)$ in the second, while interest rate is $\mathrm{I}(1)$ in all sub-periods. ${ }^{3}$ Inflation displayed little tendency to persist in the first period with inflation being followed by deflation. Different orders of integration cannot, however, be used as evidence to refute the Fisher relation.

\section{Testing for cointegration}

Despite mixed evidence on the integration properties of inflation and interest rates, a cointegrating relationship is found for the full sample using the standard Johansen framework (Johansen, 1988). The results are presented in Table 3.

The trace statistics (LR test) indicate one cointegrating equation at a $1 \%$ significance level. The null that $r=0$ is rejected at a $1 \%$ significance level means that a meaningful

\begin{tabular}{|c|c|c|c|c|c|c|c|c|}
\hline & \multicolumn{2}{|c|}{$1900-2000$} & \multicolumn{2}{|c|}{ 1900-1935 } & \multicolumn{2}{|c|}{ 1936-1970 } & \multicolumn{2}{|c|}{$1971-2000$} \\
\hline & $i_{t}$ & $\pi_{t}$ & $i_{t}$ & $\pi_{t}$ & $i_{t}$ & $\pi_{t}$ & $i_{t}$ & $\pi_{t}$ \\
\hline Obs. & 101 & 101 & 36 & 36 & 35 & 35 & 30 & 30 \\
\hline Mean & 4.90 & 4.29 & 3.05 & 1.84 & 2.94 & 3.77 & 9.42 & 7.81 \\
\hline Std. deviation & 3.73 & 6.62 & 1.19 & 8.41 & 2.39 & 3.30 & 3.12 & 5.70 \\
\hline Jarque-Bera & 16.5 & 22.7 & 0.72 & 5.54 & 3.42 & 41.47 & 1.62 & 6.93 \\
\hline Probability & 0.00 & 0.00 & 0.698 & 0.06 & 0.18 & 0.00 & 0.44 & 0.03 \\
\hline
\end{tabular}
long-run relationship exists between interest rate and

Table 1. Sample statistics, full sample and sub-periods

\footnotetext{
${ }^{3}$ Results are available upon request.
} 
Table 2. ADF unit-root tests for full sample

\begin{tabular}{llllllll}
\hline & $\alpha_{0}$ & $t_{\alpha 0}$ & $\alpha_{1}$ & $t_{\alpha 1}$ & $\alpha_{2}$ & $t_{\alpha 2}$ & $t_{\beta k}$ \\
\hline$\pi \sim \mathrm{I}(0)$ & 0.69 & 0.669 & 0.02 & 1.142 & -0.40 & $-4.462 * *$ & 0.301 \\
$i \sim \mathrm{I}(1)$ & 0.014 & 0.487 & 0.01 & 1.797 & -0.148 & -2.831 & 1.557 \\
$\Delta i \sim \mathrm{I}(0)$ & 0.05 & 0.179 & -0.0003 & -0.069 & -1.185 & $-8.899 * *$ & 3.016 \\
\hline
\end{tabular}

** Denotes $1 \%$ significance level and number of lags $(k)$ reported is one.

Table 3. Johansen cointegration test

\begin{tabular}{lcccl}
\hline Eigenvalue & Likelihood ratio & $5 \%$ critical value & $1 \%$ critical value & Hypothesized no. of CE(s) \\
\hline 0.183521 & 21.29348 & 15.41 & 20.04 & None ** \\
0.018873 & 1.829135 & 3.76 & 6.65 & At most 1 \\
\multicolumn{2}{l}{ Normalized cointegrating coefficients: one cointegrating equation } & \\
TBR3MUK & CPINFUK & C & \\
1.000000 & -1.354808 & 1.008618 & \\
& $(0.45501)$ & & & \\
Log likelihood & -448.3672 & & & \\
\hline
\end{tabular}

** Denotes rejection of the hypothesis at $1 \%$ significance level.

inflation. The normalized cointegrating equation in vector notation in Table 3 can be written as:

$$
i=-1.01+1.355 \pi
$$

This relation suggests that a $1 \%$ increase in inflation leads to a $1.355 \%$ increase in interest rates in the long run. The figure in parentheses in the table under the estimated normalized coefficient is the standard error, which is significant. Since cointegration exists, all variables are stationary (Johansen and Juselius, 1992). The errorcorrection term obtained from the above equation is also found to be stationary.

The implication of this Fisher result is that the central bank can influence a yield curve through the short-term interest rate, which is determined by inflation expectations. For example, the average inflation declined from $11.6 \%$ during period $1970-1984$ to $4.15 \%$ during period 1985-2000, leading to declines in nominal interest ratesa notable achievement of macroeconomic policy in recent times. There is little doubt that monetary policy can influence short rates, but the long rates can be determined in part by the return on productive investments, aside from inflation expectations.

\section{CONCLUSIONS}

With the long-run relation between nominal interest rates and inflation being country and period dependent, the Fisher relation for the UK was investigated via the Johansen cointegration test, using annual data over the last century. The hypothesis that nominal interest rates adjust on a one-for-one basis with the change in expected inflation cannot be rejected. In other words, the Fisher equation does exist in which the nominal interest rate is a positive function of inflation with a unit coefficient.

\section{ACKNOWLEDGEMENTS}

This paper builds on the first author's unpublished paper entitled 'The Fisher Relation Revisited: Evidence from 1885-1914 Britain', presented at AMEX on 10 June 1999 (with N. Ferguson). We are grateful to N. Ferguson for having provided the historical time series data. All errors, however, are our own.

\section{REFERENCES}

Barsky, R. (1987) The Fisher hypothesis and the forecastability and persistence of inflation, Journal of Monetary Economics, 19, 3-24.

Crowder, W. J. and Hoffman, D. L. (1996) The long-run relationship between nominal interest rates and inflation: the Fisher equation revisited, Journal of Money, Credit, and Banking, 28(1), 102-18.

Dolado, J. J., Jenkinson, T. J. and Sosvilla-Rivero, S. (1990) Cointegration and unit roots: a survey, Journal of Economic Surveys, 4, 249-73.

Evans, M. D. and Lewis, K. K. (1995) Do expected shifts in inflation affect estimates of the long-run Fisher relation?, Journal of Finance, 50(1), 225-53.

Fama, E. (1975) Short-term interest rates as predictors of inflation, American Economic Review, 65, 269-82.

Ferguson, N. (2001) The Cash Nexus, Money and Power in the Modern World, 1700-2000, Allen Lane, The Penguin Press, London.

Fisher, I. (1930) The Theory of Interest, Macmillan, New York. 
Granville, B. and Rockinger, M. (1997) Testing the Fisher relation: the Russian case, Les Cahiers de Recherche, CR 601/1997 (Groupe HEC).

Johansen, S. (1988) Statistical analysis of cointegrating vectors, Journal of Economic Dynamics and Control, 12, 231-54.

Johansen, S. and Juselius, K. (1992) Testing structural hypotheses in a multivariate cointegration analysis of the
PPP and the UIP for UK, Journal of Econometrics, 53, 211-44.

Mishkin, F. S. (1992) Is the Fisher effect for real? A re-examination of the relationship between inflation and interest rates, Journal of Monetary Economics, 30, 195-215.

Taylor, M. P. (1999) Real interest rates and macroeconomic activity, Oxford Review of Economic Policy, 15(2), 95-113. 